\title{
VICARIOUS LIABILITY AND ADMINISTRATION OF RISK II
}

\author{
WILLIAM O. DOUGLAS
}

I

In an earlier part of this article ${ }^{1}$ a translation of the rules of frolic and detour and independent contractor into administration of risk concepts was attempted. The case of the person to whom the loss was allocated was considered to ascertain what his capacity was to administer it. The analysis undertaken there will be extended here to some of the partnership and business trust problems. The capacity of the persons being held liable to administer the risks allocated to them will be studied. Contract as well as tort liability will be included. But only those problems will be analyzed which involve the determination of what persons are vicariously liable for contracts and torts admittedly within the scope of the business being undertaken. Questions of the scope of the authority or power of the so-called agent will not be included.

\section{II}

\section{PARTNERSHIP}

If $A$ and $B$ are co-owners of a business, in the sense that they share profits equally, have each made the same contribution to capital, hold the property used in the business in common and share jointly in the management, they are beyond doubt partners. If they borrow $\$ 10,000$ from $C$ for a year and agree to pay $C$ one-fourth of the net profits of the business for the term of the loan, the question of $C$ 's liability for the torts and contracts of $A$ and $B$ may be put in issue. It quite naturally arises in the query, are $A, B$ and $C$ partners?

It is legal history that $C$ at one time would have been liable as a matter of law in most jurisdictions. ${ }^{2}$ It is also legal history that an emasculation process set in. Some of the phases of that

1 This is the second and concluding instalment of Douglas, Vicarious Liability and Administration of Risk I (1929) 38 YALE L. J. 584.

2 Waugh v. Carver, 2 H. Bl. 235 (1793); RowLEY, PARTNensirr (1916) $\S 51$ et seq. A strong indictment against this rule is set forth in Eastman v. Clark, 53 N. H. 276 (1872). 
process might be stated, well known as they are. If $C$ had been given a right to a sum equal to one-fourth of the net profits, liability would not follow as a matter of law. If $C$ had been given the share of net profits as compensation for serrices, such liability would not follow. ${ }^{-}$By statute at least one state decreed that such liability would not be imposed if the net profits were to be received in lieu of rather than in addition to interest. Miany cases began to draw distinctions where the arrangement was more clearly earmarked as a security device, arianged between debtor and creditor,,${ }^{\circ}$ and a sharing of gross receipts was sometimes made an exception. These unsubstantial distinctions were maintained in some jurisdictions though Co: $i$. $H_{i c k m a n}{ }^{s}$ is reputed to have changed the rule of Wa'gh $2 . \mathrm{Car}^{\circ}$ ver and established a different test. ${ }^{\circ}$ Its actual holding will be considered at length later. A reading of the opinions of the Lords in the case reveals that different language was being used; that a new articulation was being attempted; and that a new analysis was under way. Some of the opinions in that case vere flavored with the concept "principal and agent." ${ }_{10}$ Subsequent opinions followed the mode. Was there a reciprocal agency? Were the parties jointly interested in the business? These and variations of them were sometimes expressed directly and indirectly under the guise of "intention"-_did the parties by what they did express an intention to be partners? ${ }^{11}$ Subsequently came the Uniform Partnership Act stating: "A partnership is an association of two or more persons to carry on as co-owners a business for profit." ${ }^{12}$ These are the terms in which the apologiae of judges are being dressed. What holdings are they used to describe? It is singularly significant that the evolution of this branch of the law has produced no test that is definite; that in spite of the innumerable rulings it is difficult to assert with any finality the factual variations which create a partnership. However all is not chaos. One test has been devised which not only quite adequately squares the decisions since Co: $v$. Hickman,

${ }^{3}$ See Catshill Bank v. Gray, 14 Barb. 471 (N. Y. 1S51).

4 Burckle v. Eckhart, 1 Denio 337 (N. Y. 1845).

5 Wessels \& Co. v. Weiss \& Co., 166 Pa. 490, 31 Atl. 247 (1895).

- Richardson v. Hughitt, 76 N. Y. 55 (1879); Cassidy v. Hall, 97 N. Y. 159 (1884).

7 See Dry v. Boswell, 1 Camp. 829 (1808).

s 8 H. L. Cas. 268 (1860).

9 Rowlex, op. cit. supra note $2, \$ 43$ ct seq. For the evolution of the English law see LiNDley, PARTNERship (9th ed. 1924) 57 ct scq.

10 See the opinions of Lord Cranworth (pp. 303-306) and Lord Wensleydale (pp. 311-314).

11 Mollwo, March \& Co. v. Court of Wards, L. R. 4 P. C. 419, 435 (1872).

12 Uniforat PARTNerseip AcT, $\$ 6$ (1). The English Act, 52 \& 54 Vict. c. $39, \S(1)$, provides: "Partnership is the relation which subsists between persons carrying on a business in common with a view of profit." 
but also furnishes an acceptable rationale for them. It is the entrepreneur theory of liability. Since much that is to follow proceeds from the basis on which that theory rests, a statement of it seems necessary.

This test was borrowed from the fields of principal and agent, and master and servant. The rules of vicarious liability found were rationalized on the ground that these losses which were being allocated to the enterpriser were cost items which the business should bear. They were hazards which the business incurred. If they were treated as cost items, the consumer of the product would ultimately pay them as they would normally be passed on to him. It was reasoned that these were costs which the consumer should pay; that it was difficult to differentiate between these items and any other cost items. It was concluded that no one enterprise was discriminated against; that all members of a competitive group were treated alike; that a premium was put on efficiency. This was the rationale of the negligence cases in master and servant and the undisclosed principal cases in principal and agent.13 The transition to the question, who is liable as a partner, was not great. In frolic and detour, the enterprise and the enterpriser were known. The problem was largely one of determining what the cost items were to be. In the independent contractor cases the identity of the enterprise to be held liable had to be ascertained. In the partnership cases here involved the limits of the enterprise are fixed and certain. The only question is, who are the enterprisers? Though the three problems have those differences they all rest on the basis that the enterpriser is the one to whom these types of losses should be allocated.

So the problem resolved itself into a search for the co-enterprisers in the partnership cases. To ascertain who the co-enterprisers were the following dual process was used.14 In the first place a voluntary association of the alleged enterprisers was necessary. This was deemed essential in view of the commonlaw stress on the consensual relation. An agreement between the alleged enterprisers to act together was a sine qua non.10 It would change three separate enterprisers into three co-enterprisers. Once it was clear that various parties had associated together the next step was to ascertain if those who had become associated were in fact co-enterprisers. An analysis was made of the facts in each case. This was effected by use of the four earmark test of control, ownership, profits and losses. (1) Con-

${ }^{13} \mathrm{~A}$ similar statement is contained in the earlier article. See Douglas, op. cit. supra note 1 , at 585 et seq.

${ }^{14} \mathrm{~A}$ statement of this analysis is to be found in (1922) 22 CoL. L. REV. 576.

15 The landmarks on the point are Hoare v. Dawes, 1 Dougl. 371 (1780); Burnett v. Snyder, 76 N. Y. 344 (1879); Wild v. Davenport, 48 N. J. L. 
trol. The ability to formulate and to execute policies, i. c., to make decisions in respect to the production or marketing functions. (2) Ownership. The legal (or equitable) title to the property used in the performance of the production or marketing functions. (3) Profits. The chance to receive monetary gain by sharing in the net income of the business. (4) Losses. The investment which is staked on the success of the venture. The agreement which the parties had made would normally reveal the way in which these various incidents or earmarks had been allocated. The allocation necessary to constitute co-enterprisers would be a sharing of a major number of these earmarts in addition to the agreement to associate. If there had been an allocation to all of them of the four earmarks, they would undoubtedly be enterprisers, and, having agreed to act together, co-enterprisers. Hence they should be liable. If those sought to be held liable as partners had been allocated but one of the four earmarks they obviously would not have the differentiating earmarks of enterprisers. Consequently they should not be liable. If they had but two of the four earmarks and had agreed to associate, they would approach more closely the description of co-enterprisers. But he who had the burden of establishing that they were co-enterprisers had obviously failed since he had not established it by a preponderance of the evidence. Hence no liability should follow. It would be established that they were co-enterprisers and liability would follow if instead of having one or two earmarks, they had three of the four earmarks, and had agreed to associate. By a preponderance of the evidence it would appear that they were co-enterprisers.

This test on the whole explained the cases quite well. Those who had become associated together and shared the four earmarks obviously would be liable. ${ }^{10}$ Those who, though associated, had but one of the earmarks were not held liable. ${ }^{17}$ Similarly

129, 7 Atl. 295 (1886). Consistently with this the Unurorar Partsersirip ACr, $\S 18(\mathrm{~g})$ provides: "No person can become a member of a partnerahip without the consent of all the partners."

16 It would be impossible to satisfy more fully the requirements of the UNIFORM PARTNERSHIP ACT, $\$ 6$ (1): "A partnership is an ascociation of two or more persons to carry on as co-owners a business for profit." 17 Boston Co. v. Smith, 13 R. I. 27 (1880) is representative. Liggett v. Hyde, 58 N. Y. 272 (1874), and similar cases adhering to the rule of Waugh v. Carver, supra note 2, are of course contra. Mrollwo, March \& Co. v. Court of Wards, sipra note 11, could be analyzed under the cntrepreneur test as follows: the Rajah shared profits as he was to be paid a fraction of the net profits antil his claims were repaid. This is sharing profits as an entrepreneur shares them. He did not bear losses as his agreement was to forbear suit and not to release. He was not a co-owner with the Watsons though he was an equitable mortgagee. The interests of mortgagor and mortgagee are different. Co-ownership would imply the same type of interest. Thus the most the Rajah could have would be 
for those who had but two of the earmarks even though an association could be found. ${ }^{18}$ But when an association was present and three of the four earmarks, liability was normally imposed. ${ }^{19}$ Though such theory of liability was not articulated by the courts, nor clearly recognized in the opinions, it squared the decisions quite well. And it furnished a rationale consistent with the apologiae of the judges. ${ }^{20}$ And it did more than that. It afforded an acceptable, workable economic basis for a liability rule.

The following analysis proceeds on that basis. It is submitted that such entrepreneur theory of partnership liability is by far the best that has been suggested. It rests on sound bases. The only criticism is in its application. It is this. As' stated, the enterprisers are sought because they are in a position to effectuate a distribution of the losses allocated to them among the consumers of the product. It is admitted that those who are fullfledged entrepreneurs have that capacity. But it is not agreed

profits and control. And control is exceedingly doubtful since in no realistic sense does he share in policy formulation. His only control is negative. He may veto, but only veto. He and the Watsons do not share the same type of control. And the type the Rajah had is not an entrepreneur's type. Therefore it seems as if the Rajah had but one earmark-profit sharing. The case therefore seems correctly decided.

${ }_{18}$ Cox v. Hickman, supra note 8. In this case the cestuis wore associated as evidenced by the fact that they joined in the deed of arrangement and made provisions for meetings for the exercise of the control reserved. They had the loss earmark as each released his claim against the Smiths. They shared control as they were vested with full supervision over tho trustees and could make rules as to the mode of conducting the business. They did not share profits as entrepreneurs share profits, as they could only be repaid the amount of their respective claims. They were not co-owners though each had an equitable interest under the trust, since the interest of each was so diverse from the interest of the other. The similarity and permanency in tenure needed was lacking. In Parker v. Fergus, 43 IIl. 437 (1867), the person sharing in profits and losses was not held liable.

10 Buford v. Lewis, 87 Ark. 412, 112 S. W. 963 (1908). There Lewis was sharing profits. The loss earmark seems present since advances wero made not covered by the mortgage. While he entrusted his associato with "the entire management and control of the business" it seems as if ho had the right at any time to share in policy formulation.

20 "Co-enterpriser" is a fit substitute for "co-principal," and "enterprisor" for "principal." In Malvern Nat. Bank v. Halliday, 195 Iowa 734, 739, 192 N. W. 843,846 (1923), the entrepreneur test was more clearly articulated than in any other opinion which has been found. The court said: "Tho salient features of an ordinary partnership are (1) a community of interest in profits and losses (2) a community of interest in the capital employed and (3) a community of power in administration. These are the primary tests and constitute the indicia of the existence of a partnership." Raroly is it so well put. It is usually hidden in the connotations of principal and agent. 
that an allocation of any of the three earmarks gives those who have them such capacity. In other words the entrepreneur test is a test that descriptively differentiates those who are enterprisers from those who are not. It does not necessarily differentiate those who have the capacities of enterprisers from those who do not have such capacities. Or to be more precise, the entrepreneur theory does not per se have the quality of measuring the capacity of individuals to absorb the losses allocated to them. The existence of that capacity is the premise from which the theory proceeds. But in its application it overlooks its purpose. In its eagerness to differentiate the entrepreneur from the capitalist, wage earner etc., it has adopted a test which has made such differentiation but which is not always compatible with a capacity test. It is with a capacity test that we are primarily concerned.

That capacity is measured by the ability to distribute these newly added cost items through the channels which the respective businesses provide. It is circumscribed by the ability to shift and distribute risks. As indicated in the earlier part of this article, ${ }^{21}$ risk shifting describes the process of transferring immediately to another the risk of a certain disadvantageous event happening. This is normally done through the insurance device. Risk distribution is on the other hand a phase of risk assumption. The risk of the event is assumed and protection against it is secured in advance by the creation of a surplus or reserve. Or instead of being secured in advance it may be assumed without such security and if a loss occurs on the happening of the event, the loss will be absorbed by being distributed along with all other cost items.

There are but few instances where risk shifting devices are available in modern society. Those are tort cases. The forms of liability insurance are the devices available. No comparable device appears in the contract cases. While an employer may shift the risk of liability for his truck driver's' negligence, he cannot shift the risk of liability for his salesmen's improvident, unwise, unauthorized contracts. There is no device for effecting the shift. But in the tort cases where the risk shifting devices are available the problem arises, what persons should the court hold liable as partners if it were interested in holding liable those who stood in a strategic position to shift the risk? Obviously cognizance that a risk exists and access to an insurance market would each be a sine qua non. But no detailed analysis of what would constitute such cognizance is necessary since no problem

${ }^{21}$ See Douglas, op. cit. supra note 1 , at 588. A translation of these various rules of liability into risk avoidance and risli prevention coneepts has been arbitrarily excluded from this paper. It is not thought that they are wholly unimportant. 
of risk shifting is separate from the problem of risk distribution. This is true since it costs money to shift risks. Hence with each shifting of risks there is inseparably bound up a problem of distributing the cost of shifting. So no matter whether a $\$ 5000$ tort judgment, or a $\$ 5,000$ contract judgment, or the cost of shifting the risk of the $\$ 5000$ tort judgment is involved, the problem of distribution of losses is present. Thus the problem reduces itself to an analysis of the earmarks not of co-entrepreneurs but of those who have the capacity to do what co-entrepreneurs can do-i.e., distribute the risks.

If full-fledged co-enterprisers know that a certain loss is going to be allocated to them, they can build up a reserve to handle it in advance. If they have been forced to pay without having built up a reserve to cover the loss, they can recoup the loss in the same manner in which the reserve was constituted. That would seem theoretically possible in one of two ways or in a combination of the two. (1) The price of the commodity sold could be increased so that there would be an increased profit. The increase would be approximated to the loss. Thus the reserve would be constituted, or the recoupment be effected. (2) The increased profit could be secured by decreasing other costs so as to get a greater differential between cost and price. Here also the increase would make up the reserve or be the source of recoupment. Thus in either case the absorption of these losses allocated to the enterprisers would be effected by a manipulation of this profit differential. In that way would the consumer bear the loss ultimately. In no other way would it be reallocated from the enterprisers to the consumers, for if the enterprisers had paid out of their funds a $\$ 5000$ judgment the absorption desired would not be effected by merely making the consumers pay an increased price. "They might well pay an increased price and still fail to absorb the loss in any realistic sense. For unless the enterprisers are reimbursed for their out-of-pocket expenditure, the loss will be allocated to them and not to the consumers. And it seems quite clear that the most obvious manner in which a reimbursement can be effected is through the use of this profit differential. Hence it is around the manipulation of this profit differential that the analysis of the capacity of enterprisers to distribute risks centers. Therefore the capacity of anyone other than an enterpriser to distribute risks would be determined largely by such analysis. In other words such analysis would reveal those who were constituted as effective, efficient risk distributors.

A technique is necessary for such analysis. The entrepreneur test is of only partial aid in furnishing one. Obviously whether a person has staked money or property in an enterprise, and consequently has the loss earmark, throws little light on his 
capacity as a risk distributor. He well might have that capacity with or without the loss earmark. Likewise the ownership earmark per se has little utility for such purpose. Those who have equitable title or legal title are not necessarily endowed with an ability to distribute risks. They might have such ability without title. Title per se can be discarded. The loss and ownership earmarks for this analysis are of little utility. There may be cases where they are of utility in finding the risk distributor, as for example when the facts are muddy and it is hard to find the way in which the various incidents or earmarks were allocated. Then the presence of the loss and/or ownership earmark might be of some evidentiary weight in determining that the allocation was one way rather than the other. But when the facts are clear and the precise allocation is known they can be ignored.?

It is apparent from what has been said that the profit earmark and the control earmark cannot be so summarily treated. Receipt of profits has a direct relation to the reimbursement that is necessary for effective risk distribution. Control necessary to manipulate effectively the profit differential seems essential. A consideration of the weight to be given each is therefore quite necessary.

Control is a vague concept because it is so all inclusive. It includes many types. Each type may have a different significance from the viewpoint of risk distribution. Hence it seems desirable to discard control as such and make the analysis in terms of types of control. One type of use in effecting the distribution desired is the right to fix prices. This follows from the conclusion that price fixing is one method of manipulating the profit differential. The only other type at all relevant is the right to determine the various cost items, since such regulation may result in increasing the profit differential. All other types seem quite immaterial in measuring the capacity of a risk distributor, since no other type increases that capacity.

Profit sharing is likewise not wholly free from ambiguities. It means different things. It may merely signify a right to demand payment of a sum certain-rent, interest, consideration for sale of property, etc.-out of a specific fund, i.c., net profits. Or again it may mean a right to a definite fraction of this indefi-

${ }^{22}$ Ownership of course might be significant in many ways. Since it sometimes connotes beneficial use it might mean the right to profits. Or again it might be translated into losses and mean that an investment had been staked. And again it might signify control in any or all of the ordinary meanings of the term, if the right to possession and use is implied. Ownership would not be discarded. As much cannot be said for losses. Sometimes-but not always-persons who stake a sum in a venture have the profit and control earmarks. In a given case where all the facts are not present the presence of the loss earmark might suffice to send the case to the jury. 
nite fund called net profits for or during a specified period, which may be a month, a year, ten years, until a debt is repaid, and so on. The latter type of profit sharing is considerably more significant than the former. In the first place it might be observed that the latter type is the type which differentiates enterprisers. It is the type which entitles the sharer to fortuitous, unforeseen profits. Or, more analytically, the sharer is not restricted to reimbursement for a particular amount which he has advanced to the enterprise. In the former an increase in the profits one thousand fold will mean no added increment to him. He takes his $\$ 50$ or $\$ 10,000$ and that is all. Consequently it would seem that the strict profit sharing earmark is the only type needing consideration in this analysis of the capacity of risk distributors.

The case then resolves itself into a consideration of the two types of control and the one type of profit sharing. What combination or combinations give the capacity needed? The right to share in profits as such is obviously not sufficient. No assurance is present that any manipulation of the profit differential can be effected. The ancient profit sharing test along with any profit sharing test can therefore be dismissed without more ado. ${ }^{33}$ The right to fix prices by itself is likewise ineffective. While that may result in increased net returns, it permits no sharing in that increase. In absence of such sharing there would seem to be no doubt that that person or group of persons were not risk distributors. ${ }^{24}$ And though the right to fix prices were coupled with the right to share in the profits as such, it is doubtful if effective risk distribution would result. The theoretical difficulty is less apparent than a practical one. While in theory an increased profit will result from an increased price, actually it may not. Whether or not it does depends upon the state of the market including the demand and supply as well as its competitive or monopolistic features. Consequently though prices are increased profits may remain,static or may decrease. The existence of these variables makes it exceedingly difficult to say that those who can fix the prices and who are entitled to the profits stand in a strategic position to reallocate the losses which they have been forced to assume. Much weaker is the case

${ }^{23}$ This squares with decisions like Boston Co. v. Smith, sulpra note 17, which hold that the profit earmark alone is insufficient. Sharing in gross receipts alone is likewise insufficient from this viewpoint. An increase in gross income is not assured. An allocation to the consumer is impossible without some type of control. UNIFOrM PARTNERSHIP ACT, $\$ 7$ (3) decreos no liability. The cases are in accord. Beecher v. Bush, 45 Mich. 188, 7 N. W. 785 (1881) ; Eastman v. Clark, supra note 2; Thomas v. Springer, 134 App. Div. 640, 119 N. Y. Supp. 460 (2d Dep't 1909). Contra: Champion v. Bostwick, 18 Wend. 175 (N. Y. 1837).

24 No such case has been found. From the analogy of the next group of cases liability would certainly not be imposed. 
where profits as such are shared but the right to fix the prices is contingent, for the contingency may never happen. To phrase a general rule so as to make those persons vicariously liable in either case for the losses incidental to the business would be to hold those who were not clearly effective risk distributors. The cases quite consistently refuse to impose such liability.:3 By such refusal the holdings are in line with the approach here suggested.

If in addition to sharing profits as such they have not only the right to fix prices but also the right to determine all costs it would seem that they should be liable, if this approach is taken. If any group can effect an absorption of losses that group can. The ineffectiveness in the preceding case has disappeared. The presence of the right to determine all cost items makes an effective manipulation of the profit differential as certain as possible in a dynamic society. While no absorption can be absolutely predicted and while the whole notion is purely relative due to the variations in the group being held, the business involved and the business cycle at hand, it can be safely asserted that the combination of these three rights gives the possessors the essential characteristics of risk distributors. The cases hold liable such persons as partners. ${ }^{26}$ Those holdings are as consistent with this analysis as are those which hold liable the full-fledged enterprisers.

This leaves a more difficult question, is each of the three rights specified a sine qua non? Several in-between cases can be eliminated forthwith. If the person or group sued shares profits as such and only has the right to advise and confer with those who have the right to fix prices and determine all cost items, it is obvious that the capacity necessary is lacking. No effective check on price fixing and cost determination is at hand. On these facts courts quite uniformly refuse to make the person or persons designated vicariously liable for the contracts and torts

${ }^{25}$ Kelly v. Scotto, 42 L. T. R. (X. S.) 827 (1880); Bradley v. Ely, 24 Ind. App. 2, 56 N. E. 44 (1900); Cedarberg v. Guernsey, 12 S. I. 77, 80 N. W. 159 (1899) ; Harrey v. Childs, 28 Ohio St. 319 (1876). Whitney v. Ludington, 17 Wis. 140 (1863) is apparently contra. The liability of one who had in addition to the profit earmark a contingent right to fix: prices was involved in Bleck \& Co. v. Soeffing, 241 Ill. App. 40 (1926). Liability was not imposed. The case ras decided under the Uniform Partnership Act.

The right to share in gross rcceipts and also to fix prices would likewise be insufficient. The assurance that gross income will increase is lacling. Austin, Nichols \& Co. v. Neil, 62 N. J. L. 162,41 Atl. 834 (1898) is zome authority that no liability would be imposed in such ease. The right to share in price fixing was there limited to only a few (though no doubt the major) items.

${ }^{26}$ Spaulding v. Stubbings, 86 Wris. 255,56 N. W. 469 (1893), where the profit earmark was present and full control was exercised though the 
of those conducting the business. ${ }^{2 \pi}$ This result is reached though the right to advise and confer is exercised, as long as it falls short of participation in price fixing and cost determination..$^{\text {sg }}$ These holdings square themselves with this rationale.

Where the right to share in profits as such is coupled with a right of veto of an inclusive nature, a stronger case it put. But

right to exercise it does not appear in the agreement given. Buford $v$. Lewis, supra note 19, where the profit earmark was present and no control was exercised though presumably the right to do so existed. Tho capacity to distribute losses would seem to exist whichever was true. A more recent case is Wright Co. v. Green, 196 N. C. 197,145 S. E. 16 (1928), whoro profit sharing was stipulated and sharing in policy formulation soemed tacitly provided for.

The latest case found is San Joaquin Light and Power Corporation v. Costaloupes, 274 Pac. 84 (Cal. App. 1929), holding $C$ vicariously liablo as a co-partner of $A$ and $B$ for a contract claim. $A$ and $B$ owned and operated a cheese factory. They were indebted to $C$ in an amount over $\$ 20,000$, secured for the most part by note and mortgage. They were desirous of borrowing $\$ 15,000$ more. Accordingly $A, B$ and $C$ entered into a writton agreement. It was provided that $A$ and $B$ were to ship and consign to $C$ all cheese manufactured; that $C$ was to sell the cheese at the markat prico in as large quantities as consistent with market conditions; that $A$ and $B$ were to continue to manufacture unless it was agreed between the threo that market conditions did not justify further manufacture; that $C$ should make all collections and deposit the money in a bank; that $C$ was to advance $\$ 15,000$; that $C$ was was to render stated accounts of incomo and expenses; that $A$ and $B$ were to render regular accounts of expenses; that all expenses of manufacture, storage and sale were to be paid by checks drawn by $A$ and one $D$, representing $C$; that certain salaries were to bo paid to $A$ and $B$ and $D, C^{\prime}$ s representative; that after payment of all oxpenses, the surplus was to be divided equally between $A$ and $B$ and $C$; that the agreement should continue one year during which time $A$ and $B$ need pay no interest on the money advanced by $C$; that all money advanced was to be repaid by $A$ and $B$. It appeared to be the intention of the parties to have $D$, as $C$ 's representative, share in the management of the manufacturing process. It also appeared that $D$, as $C^{\prime}$ 's representative, was actively engaged in operating the factory in conjunction with $A$ and $B$. The court said: "In the business venture involved there were two branches, as is necessary in all like undertakings, namely, manufacture and sale. In cach of these branches the association and control of Tsarnas $(C)$ was provided for. The selling end was exclusively under his control and discretion and the manufacturing end was under the joint control of tho Costaloupes ( $A$ and $B$ ) and the representative of Tsarnas (D)." Sharing in profits plus control over all cost items and the right to determino prices were present. Losses and co-ownership were absent. While liability would not be imposed under the entrepreneur theory it would be under this tost. Surely $A$ has the capacity of an effective risk distributor.

27 Thillman v. Benton, 82 Md. 64, 33 Atl. 485 (1895); Dean v. Harris, 33 L. T. R. (N. S.) 639 (1875). In Wagner v. Buttles, 151 Wis. 668, 139 N. W. 425 (1913), in addition to the right to advise was a sharing of gross receipts. King \& Co. v. Whichelow, 64 L. J. Q. B. 801 (1895). In nono of these cases was liability imposed.

28 Dean v. Harris, supra note 27. 
even so, it is not strong enough to entail liability if this rationale is followed. A right to veto prices fixed or costs which have been determined upon is at its best a clumsy device for getting into force any policy desired. For practical purposes it probably even falls short of a backhanded way of fixing prices or determining costs. Theoretically a thousand nays might be as effective as one yea. Actually business is not and could not be run that way. The use to which such veto can best be put, and for which it is devised, is as a check over improvident judgments, unwarranted acts, flagrant abuses of trust, etc. As a day-to-day business regulator it fails. One would expect, if this approach were taken, decisions holding such persons not liable as partners. The cases so hold.29 And the authority is eminent.

Instances where sharing profits as such is coupled with the right to terminate the business, ${ }^{31}$ or the right to designate some one to keep books and watch outgo, ${ }^{31}$ or the right to inspect the books and records, ${ }^{32}$ or the right to countersign checks or make deposits, ${ }^{33}$ etc. or any combination of such rights are obviously not instances where liability should be imposed. Those types of control do not give the possessor any effective check on the channels through which the distribution is to take place. The cases, therefore, quite justly refuse to allow a recovery against those persons. ${ }^{34}$

29 Foremost of these cases is Mollwo, March \& Co. v. Court of Wards, supra note 11. The latest is Martin v. Peyton, 246 N. Y. 213,158 N. E. 77 (1927), decided under the Uniform Partnership Act. The right to be advised and consulted was also reserved in the latter case. Qualified veto power in addition to profit sharing appeared in the following cases: King \& Co. v. Whichelow, supra note 27; Cassidy v. Hall, 97 N. Y. 159 (1881). In Austin, Nichols \& Co. v. Neil, supro note 25, there was a sharing of gross receipts instead of profit sharing; and the right to consult on certain matters and the right to fix prices of a limitcd number of articles. In none of these cases was liability imposed.

${ }^{30}$ Cedarberg v. Guernsey, supra note 25.

31 Holmes v. Old Colony Railroad Corp., 5 Gray 58 (Mrass. 1855).

32 Cole v. Rome Savings Bank, 96 Misc. 188, 161 N. Y. Supp. 15 (Sup. Ct. 1916) ; Boston Co. v. Smith, supra note 17; First Nat. Banli v. Hall, $150 \mathrm{~Pa}$. 466, 24 Atl. 665 (1892); Thillman v. Benton, supra note 27.

33 Parker v. Fergus, supra note 18; Bleck \& Co. v. Soeffing, supra note 25.

34 Cedarberg v. Guernsey, supra note 25; Holmcs v. Old Colony Railroad Corp., supra note 31; Cole v. Rome Savings Banl, supra note 32; Boston Co. v. Smith, supra note 17; First Nat. Bank v. Hall, supra note 32; Thillman v. Benton, supra note 27; Parker v. Fergus, supra note 18; Blecl: $\&$ Co. v. Soeffing, supra note 25. Contra: Merrall v. Dobbins, $169 \mathrm{~Pa} .480,32$ Atl. 578 (1895), where the person seeking to escape liability had the right to designate a person to keep the books and act as cashier, receive all money, deposit it in his own name and make all payments, and also the right to annul the agreement upon 24 hours' notice and assume sole and exclusive possession. Practically the same combination of types of control is present in Parker v. Fergus, supra note 18, and liability was not imposed there. 
If the right to share in profits as such is coupled with a right to fix only some of the prices and/or to determine only part of the costs, the case would seem to turn on whether or not in the particular case regulation of those prices or costs would be tantamount to regulation of all prices and costs in so far as the resulting effect on the profit differential were concerned. The leading case on the point was recently decided under the Uniform Partnership Act. $A$ owned a cannery equipped for canning vegetables. $A$ agreed to grant to $B$ the exclusive right to sell all $A$ 's canned goods for a season. $B$ agreed to endeavor to sell them and make collections for those sold. For such services $B$ was entitled to a certain commission on gross sales. $B$ agreed to furnish, if requested, all necessary cans, cases and labels for packing and to advance sufficient sums from time to time to pay for raw vegetables purchased and to pay the weekly pay rolls. $A$ agreed to repay to $B$ all such sums advanced. $A$ agreed to pay $B$ one-half of the net profits resulting' from the season's operation of the cannery. $B$ was given the right to determine the salaries and wages to be paid and if the pay roll did not meet with his approval, then he need not make any advances until it did meet with his approval. $B$ 's liability was sought as a partner with $A$ for goods sold and delivered during the term of the contract between $A$ and $B$. The court ruled that $B$ was a partner of $A$ and therefore was liable for the claim. ${ }^{35}$

The profit earmark is present. The right to fix the prices is

The case of Johnson Bros. v. Carter \& Co., 120 Iowa 355, 94 N. W. 850 (1903) is not thought to be contra to the general view. The profit sharer held liable as a partner agreed to furnish a man to keep the books and "oversee" the work. The man designated kept the books and also trans. acted all the business of buying supplies and handling funds. Tho defendant also seemed to be actively engaged in phases of the work. So it seems as if the defendant was sharing in policy formulation indirectly through his tool, the bookkeeper, and directly through his own activity.

No liability is normally imposed though the right to designate someone to keep the books is coupled with a sharing of gross receipts. McDonnoll v. Battle House Co., 67 Ala. 90 (1880).

In Hackney Co. v. Robert E. Lee Hotel, 156 Tenn. 243, 300 S. W. 1 (1927), recently decided under the Uniform Partnership Act, the lessor and lessee were held not to be partners where in addition to a specifled rent charge the lessor was entitled to one-half of the net profits and reserved the following control: a limitation upon the lessee's personal uso of the rooms in the hotel was made; the lessee was required to give his personal attention to the management and not to substitute another without the lessor's written consent; a daily statement of rooms occupied and a daily as well as a monthly statement of the business in addition to an auditor's annual statement was required; the lessee's account had to bo carried at a specified bank; the hotel had to be operated on a cash basis; the lease would be forfeited on thirty days' notice for failure to comply with the terms imposed or to pay the stipulated rent.

35 Southern Can Co. v. Sayler, 152 Md. 303, 136 Atl. 624 (1927). 
present. The right to determine some, but not all of the costs, is present. Is there enough regulation over these cost items so as to enable $B$ to manipulate effectively the profit differential? It is submitted that there is. The cost items to be determined directly by $B$ are the amounts of salaries and wages and, contingently, the amounts to be paid for cans, cases and labels. He was not given direct regulation of any other cost items, for example-price to be paid for coal, price to be paid for vegetables to be canned. Yet the regulation of the cost items specified gave him strategic control over the entire production. He could stop all output or increase it to maximum. Though he could not specify the prices to be paid for vegetables, as a practical matter he could probably prevent the purchasing of these perishable products by his control over the money supply and the produetion process. This latter may be somewhat tenuous and insufficient by itself; yet, coupled with the right to determine labor cost, it gave him effective regulation of substantially all the variable cost items. Thus $B$, having an effective regulation over the variable cost items and having the right to fix prices and to share profits, seems to have had the capacity to distribute losses. Under the theory advanced the court should hold as it did. This case is of peculiar significance not only because there are few like it but also because it was decided under the Uniform Partnership Act. At least one decision is giving to "co-owners" a profit and control meaning. In doing so it adapts itself peculiarly well to the rationale here suggested.

As mentioned, such a case is rare. The other comparable cases are hardly analogous. The right to fix some of the prices coupled with a right to fix some of the costs might possibly be sufficient. But in the cases in which they have appeared they have not seemed to give to the possessor effective manipulation of the profit differential. ${ }^{30}$ And it would take an unusually strong case to allow a partnership liability to be imposed on one whose only control was a regulation of some of the cost items, for the same reason that price fixing alone would be quite inadequate.

This analysis and the cases so far discussed imply that the right to share in profits coupled with the rights to fix substantially the prices and to determine substantially the cost items are each a sine qua mon to effective risk distribution. That would explain admirably Coxv. Hickman. ${ }^{37}$ There the defendants had

36 In Bradley v. Ely, supra note 25, the lessor of the farm in addition to sharing in the profits had the right to share in fixing the sales price of the produce and in determining the purchase price of stocl. In Austin, Nichols \& Co. v. Neil, supra note 25 , the lessor of the hotel was sharing in gross receipts and jointly with the lessee fixed the price for rooms and board. In addition a strong veto power over wages was given to the lessor.

${ }_{37}$ Supra note 8. 
formerly been creditors of the Smiths but, on not being paid, took charge of the business through a device somewhat comparable to a creditors' committee. The Smiths transferred the property to trustees in trust for the defendants until the claims were paid, and then in trust for the Smiths. The defendants released their claims. They were entitled to all the profits until their claims were paid. A majority in value of these creditors had the "full power for the general benefit of the creditors to give any directions . . . "for the present or future management" of the business. They were held not liable for a claim accruing while the business was being run by the trustees. It will be readily observed however that they had by virtue of their inclusive control over the trustees the right to fix prices and to determine all cost items. On the other hand they did not have the strict profit earmark. No matter what increase in profits, each defendant would take the amount of his original claim and no more. Hence it would follow that no reimbursement could be effected from the fund of increased profits. Consequently they would not be effective distributors of these losses. Is true profit sharing a sine qua non to liability?

$A$, the owner of a business, for benevolent reasons, assigns to $B$ all of his net profits for one year. One of the truck drivers while delivering goods negligently injures $P$ who sues $A$. No partnership question is involved. But a problem is involved which rests on precisely the same basis. It could be argued that $A$ should be held under any such risk distribution rationale as here advanced, even though he lacks the profit earmark. The reason would be that $A$ on the facts stands in a strategic position to distribute the losses. To be sure to effect a reallocation to the consumers $A$ must have a means of reimbursement. He has it. By virtue of his all inclusive types of control he can determine what the cost items are to be. If he pays a $\$ 5000$ judgment he can make that a cost item. That certainly grants him the right to withdraw from the gross receipts the $\$ 5000$ which he has paid. Under those facts he needs no profit earmark. Theoretically he needs no more than the right to determine what the cost items are to be and to be reimbursed out of the assets. Actually he needs more than that if the loss is to be reallocated to the consumer. If he does not have the right to increase by the amount of his liabilities the gross receipts-differential, there will be no assurance that the loss will not be allocated directly to him by being paid out of capital or to the profit sharer by being paid out of profits. To effect the reallocation desired it would seem necessary that he have the right to fix prices and the right to regulate all cost items. Having those types of control $A$ is in a strategic position to manipulate effectively the gross receiptsdifferential and to be reimbursed out of the increase of that fund. 
Similarly, any group of persons who shared such types of control would have co-enterprisers' capacities to distribute the losses. Profit sharing would not be essential. That is not to say that sharing profits as such would never be a sine qua non. If the right to determine costs did not include the right to make the liability in question a cost item, and to get reimbursement from the assets, profit sharing in the strict sense would be a sine qua non. For it would provide the channel for reimbursement. To state the result more directly, the right to be reimbursed is a sine qua non. At times that will make necessary the true profit earmark. Thus in Southern Can Co. v. Sayler, ${ }^{35}$ the profit earmark seems essential. The control over cost items was not allinclusive. It was restricted to only a few. The right to dictate the addition of items not mentioned is absent. That means that the only source of reimbursement will be the net profits. Without such earmark the case might well go the other way.

But the same cannot be said for Cov v. Hickman. It does seem as if the defendants in that case actually were vested with as much control as $A$ had in the hypothetical case. The trustees were their instrumentalities. They could give the trustees directions for the operation of the business. This right was subject to no qualification. It seems quite clear, therefore, that they could determine all cost items, that they could make themselves creditors for amounts which they might expend, that they could manipulate the gross receipts-differential and from those returns be reimbursed. While this may not be beyond all doubt, it seems necessary to make this assumption in order to dispose of the case with finality. But even so the case need not be decided differently. Each of the partnership cases before the courts has probably been a pathological case. The business is insolvent. All talk of the particular defendants actually distributing the losses and reallocating them to the consumers may be fiction. The respective businesses before the court may not be effective absorbents. Few insolvent businesses are. The justification, however, of the rationale of risk distribution is that the rule of law is made not only for the pathological case before the court but for the general run of business. Therefore the rule of law which is fashioned should be correlated to the relatively normal rather than to the relatively abnormal type-fact situa-

\footnotetext{
38 Supra note 35 . Under the entrepreneur test this case would seem to go the other way. The profit and control earmarks are present. The agreement to repay all advances removes the loss earmark, and there was no co-ownership of property. The fact that $B$ was given a lien upon all goods packed at the cannery as security for his advance does not establiah a co-ownership in the same interest. Just as there is no co-ownership between mortgagor and mortgagee so there is none between lienor and lienee. Association, profits and control under the entreprencur test would be insufficient.
} 
tion with which it deals. Through the medium of a pathological case a rule is made for cases that are not pathological. In Cox v. Hickman there is a pathological case. But when the type-fact situation there involved is placed in its normal environment it does not change. It remains pathological. The business taken over and operated by creditors is usually in a bad way. If insolvency is not present, it is imminent. It is a known fact that creditors do not resort to this liquidating device unless the enterprise is in a precarious position. ${ }^{39}$ If the losses are to be absorbed and reallocated to the consumers, the reallocation must be effected not only through an insolvent medium but a medium which promises to remain insolvent during the transient control of the creditors. It is unlikely that if the cestuis in Cox v. Hickman were saddled with a $\$ 5000$ judgment they could effect a reallocation. They are in charge of the business because their own claims have not been paid. If they are held liable, their claims against the business will be increased. The fact that the income has not been sufficient to pay their own claims makes it quite unlikely that it can be increased to take care of these additional items. In other words if the cestuis were made liable, the chances are that the loss would be allocated, not to a medium which could effect a reallocation to the consumers, but to a medium which would have to absorb it within itself. There may be exceptions. Thus there might be a case of an insolvent but going concern with creditors in full control. If that were the fact situation present in Cox v. Hicliman, the rationale suggested would not explain the holding. But the general rule of law should not be made for such exceptional cases.

On the other hand it might be argued that, following the preceding analysis, a similar rule of law might be made for all pathological cases. All insolvent business units lacking such absorbent qualities might be dealt with alike. Thus before the creditors take charge of the insolvent business, and after they relinquish their control and turn it back to the debtor in an insolvent condition, the pathological nature of the case may be said not to have changed. The business unit at hand may be in no realistic sense an effective absorbent immediately before, during, or immediately after the creditors' regime. Even so the case of creditors is materially different from the case of the insolvent entrepreneur. Creditors step into the picture when insolvency has arrived. The opportunity to build up the reserves to take care of the losses is not available. That opportunity would exist in the solvent stages of the business, but at no time have the creditors been in control of a medium through which absorption can be effected. The strategic position which the original entre-

${ }^{30} \mathrm{Cf}$. Dewing, The Financial Policy of Corporations (1926) 11331162. 
preneur had in respect to providing for the losses is lacking. The case for liability of the creditors is weaker by comparison. As of the insolvent period the entrepreneur may not be an effective absorbent. Before insolvency set in he was. At no time were the creditors. That factor accentuates the pathological nature of the case of the creditors. It also emphasizes that insolvency should not relieve the entrepreneur under the rationale advanced. His capacity to administer this particular loss should be determined not solely by his capacity when insolvent. His capacity to administer the risk of this particular loss rather than his capacity to administer this particular loss should be measured. The former capacity is measurably greater than the latter. To be sure, the judgment will allocate the loss to him and he will no doubt be unable to reallocate it to the consumers. But he and others like him had the opportunity to create a reserve good against the risk of loss in question. The fact that they were unskilled, inefficient, or unintelligent, and did not provide for it is no extenuating factor. A rule which makes allowance for the efficient and conforms itself to their capacities may be said to rest on good policy.

There is a further reason for distinguishing between the creditors in control and the insolvent enterpriser and for making a different rule for each. It is the absence of the true profit earmark in the former and its presence in the latter. While it is true that the presence of the profit earmark is not essential for the purpose of creating the capacity to distribute risks, it is important for another purpose. That purpose is compensation for risk bearing. As previously stated, the capacity to distribute risks is relative and not absolute. The reason is patent. Demand, supply, competition, the business cycle, etc. are variables that deny at times the existence of that capacity. The risk that the capacity will not or does not exist is therefore real. The presence of such risk is not sufficient, as indicated above, to deny the validity of the premise on which this rationale rests. But it is of sufficient importance to be recognized. Its presence means that the person or group of persons to whom the court allocates the loss may have to absorb the loss without effecting a reallocation. Some compensation for bearing that risk should be present. The full-fledged entrepreneur receives his compensation in his right to the profits. Genuine co-enterprisers receive their compensation in their profit earmark." The creditors in Cou $v$. Hickman receive no such compensation. If they are held liable, they are forced to bear the risk of not being able to distribute the losses allocated to them without being recompensed for taking that risk. The factor is particularly accentuated in view of the extreme pathological nature of the case. While the profit

${ }^{40}$ Cf. 2 Botcke, Principles of Econonics (1925) 152 et scq. 
earmark may disappear as a sine qua non to effective risk distribution, it reappears as a sine qua non to liability for a different reason. The case where profits are completely separated from full control is rare. The hypothetical case given is not known. Liability might well be imposed under the rationale advanced, but denied because of the absence of, compensation, in the form of the profit earmark, for the risk assumed. Though that case may be doubtful because of the minimized risk due to the solvent condition of the business, Cox $v$. Hicleman is beyond doubt. The risk looms up large. It is substantial. If compensation for risk bearing is needed in any case, it is in that case. The problem then in any case, where full control is present and the profit earmark is absent, is to weigh the capacity to distribute risks as against the absence of compensation for assuming the risk of not being able to do so. In respect to a solvent, going concern, there might be reasonable differences of opinion. In respect to the insolvent, pathological case at hand in Cox v. Hickman, the absence of both factors seems to put the case beyond doubt. For these various reasons Cox v. Hickman can be sustained. And it is singularly significant that almost without exception, both before and after the Uniform Partnership Act, the courts when making rules for the same or analogous type-fact situations have followed Cox v. Hickman.41

So much for the insolvent entrepreneur and the creditors in control of an insolvent business. But the case of the debtor

41 Wells-Stone Mercantile Co. v. Grover, 7 N. D. 460,75 N. W. 911 (1898); Davis v. Patrick, 122 U. S. 138, 7 Sup. Ct. 1102 (1887); In ro Hoyne, 277 Fed. 668 (C. C. A. 7th, 1922). The last case was decided under the Uniform Partnership Act. Creditors of a badly involved brokerage firm took charge of the business. The assets of the firm were transferred to a new firm which assumed the debts. The creditors agreed with the members of the new firm that the latter were to continue the business; that a managing committee of creditors be designated with "full power to supervise and control" the business until the indebtedness be paid off; that the right of the partners of the firm to carry on and mannge tho business be subject to the supervision and control of such committec; that in case of disagreement the determination of the managing committeo bo final; and that the net earnings be applied to pay off the claims. The members of the new firm were adjudged bankrupts. A petition to vacato was filed on the ground that these creditors were also partners of tho members of the firm adjudged bankrupts and that there was no insolvency as a result. An order dismissing the petition was affirmed.

Purvis v. Butler, 87 Mich. 248, 49 N. W. 564 (1891) seems contra, though the state of the business taken over and managed by the creditors does not appear. Presumptively it seems on all fours with the preceding cases. Righter v. Farrel, $134 \mathrm{~Pa}$. 482, 19 Atl. 687 (1890) is hardly contra since the creditors took over the business completely, later became partners in it and did business as such. This may be the case of an insolvent, going concern which is an effective absorbent. Conceivably that was also the situation in Purvis v. Butler, supra. 
whose business is commandeered by his creditors is obviously different. For claims arising during the term of creditors' control he should not be liable. To be sure he has the true profit earmark since fortuitous, unusual profits will redound to his benefit. But during the term of creditors' control he does not share in policy formulation in any sense nor supervise or control in any way those who are formulating policies. When all such control disappears the sine qua non of effective risk distribution disappears also. And there is authority that liability would not be imposed. ${ }^{12}$

\section{III}

JOINT STOCK COMPANY AND EUSINESS TRUST

If the preceding analysis is applied to the cases involving the liability of members of a joint stock company and of cestuis of a business trust for claims incurred in the operation of the business, one fact variation will be noticed immediately. Those being sued are not the managers in the colloquial sense. The managers are the directors of the joint stock company and the trustees of the business trust. Those sued have only a supervisory type of control. They do not formulate policies as partners normally do. They merely supervise those who formulate policies. The degree of supervision depends on the types of control reserved. It is around these types that the analysis centers. The purpose will be to weight these various types according to the degree in which they endow those who may exercise them with the capacity to distribute the losses in issue.

The mere fact that this control may be residual or supervisory does not deny it factual strength for the purpose at hand. The members of a joint stock company elect directors. They determine the tenure of office. While they do not have the right to formulate policies, and hence can not as a matter of right directly fix prices and determine costs, they can elect as managers those who will formulate the desired policies. Furthermore, having elected their representatives their hands are not tied if the policies desired are not forthcoming. Those elected can be removed and more obedient representatives can be substituted.s ${ }^{\text {ts }}$ Thus

42 Wells-Stone Mercantile Co. v. Grover, supra note 41 . The court said at 473: "The instrument placed the control of the property and the business entirely beyond the assignor so long as the trust should continue."

43 The statutory restrictions on the right of shareholders to remove direetors of a corporation do not apply here. The members and the directors seem able to make any contract they wish. Removal with or without cause would be permissible. This is consistent with New YORK GeNernu ASSOCIATIONS LAW, $\S 3$ that, "The articles of association of a jointstock association may: ... (2) Prescribe the number of its directors, 
while the members of the joint stock company are one step removed from the fixing of prices and the determination of costs, they seem not so far removed as to become ineffective regulator's thereof. That, coupled with the fact that their claim to the profits gives them beyond doubt a source of reimbursement, gives them the capacity to distribute losses as required by this rationale. For these reasons the decisions seem consistent herewith when the members are held liable as partners. ${ }^{44}$ They not only have co-enterprisers' capacities. They are co-enterprisers. ${ }^{40}$

The business trust cases are more complicated. The complication arises because of the varied types of control allocated to

not less than three, to have the sole management of its affairs. (3) Contain any other provision for the management of its affairs not inconsistent with law." In New York it would not seem that a rule more strict than that existing in respect to corporations, Matter of Schwartz, 119 Misc. 387, 196 N. Y. Supp. 679 (Sup. Ct. 1922), would be established. The reservation in the articles of the right of the shareholders of a joint stock company to remove the directors was implicitly approved, though not involved, in Spraker v. Platt, 158 App. Div. 377, 387, 143 N. Y. Supp. 440, 447 (3d Dep't 1913), where the court said: “. . . we find no provision of law prescribing the manner in which the directors shall be chosen, nor limiting the right of a voluntary association to itself prescribe the mothod of choosing directors, nor fixing a definite term of office ..." There is authority that the right exists in England. Isle of Wight Ry. Co. v. Tahourdin, 25 Ch. D. 320 (1884); Browne v. La Trinidad, 37 Ch. D. 1 (1887) ; 8 EDW. 7 , c. 69 , Sched. 1, No. 86 (1908); 1 LINDLEX, LAw of CoMPANIES (6th ed. 1902) 418. The reservation in the articles of joint stock associations'of the right of shareholders to elect and remove, or elect and supervise, the directors seems quite common. The indenture reserved the right of election and removal to the shareholders in Carlen v. Drury, 1 V. \& B. 154 (1812). The validity of the provision was tacitly approved by Lord Eldon who dismissed a bill for a dissolution prayed for on the grounds of mismanagement, because the redress furnished by the indenturo should have been tried first. In Harrison v. Heathorn, 6 Mnn. \& G. 81 (1843), the deed of settlement gave to the shareholders the right to prescribe all directions and regulations for the operation and management of the property and to make any rules for the management which they saw fit. Cf. Baird's Case, 5 Ch. App. 725, 734 (1870); Reffon Realty Co. v. Adams Land \& Bldg. Co., 128 Md. 656, 661, 98 Atl. 199 (1916).

44 Carter v. McGlure, 98 Tenn. 109, 38 S. W. 585 (1896); Cutler v. Istato of Thomas, 25 Vt. 73 (1852); Ashley v. Dowling, 203 Mass. 311, 89 N. E. 434 (1909); cf. Hibbs v. Brown, 112 App. Div. 214, 98 N. Y. Supp. 353 (1st Dep't 1906). If the shareholders were shorn of all control the caso would go the other way under the approach here taken. Or if the control reserved was ineffective for the purpose at hand, the result would bo different. No such abnormal cases involving the liability of shareholdors of a joint stock company have been found. The fact that thoy are joint stock companies would not suffice, for as has been seen, supra note 43 , in absence of statute the shareholders' rights depend on contract and tho variations in contracts are many. If the allocation of control to the shareholders is normal, the results indicated should follow.

45 Undex the entrepreneur test liability would no doubt be imposed. Tho element of association is always present as are the four earmarks. 
the cestuis. Where the cestuis have no control whatsoever over the trustees (except that which a court of equity always gives to every cestui) the majority hold that the cestuis are not personally liable. ${ }^{18}$ Since the cestuis cannot as a matter of right take a hand in fixing prices or determining costs they completely lack the capacity, which full fledged co-enterprisers have, to distribute losses. Their profit earmark is obviously insufficient, as has been noted. Such holdings seem quite consistent with this analysis. They are likewise consistent with the entrepreneur test, where there has been no association. But under the risk distribution theory an association would be of no significance unless it was an association for the purpose of exercising the types of control which this test weights. An association per se might have signifiance for some purposes but certainly none under this theory. Provisions for meetings at which the trustees would read reports to the cestuis would be meaningless from the angle of administration of risks. ${ }^{47}$ Liability should not therefore be imposed. The case for liability is clear where the cestuis have been allocated rights to make rules for the conduct of the business and to direct the trustees in any matter. The capacity of cestuis in that case to distribute the losses is certainly as great as that of the members of a joint stock company, for no doubt the right to direct carries with it by implication the right to enforce the direction. To impose liability is to conform to the theory presented.18

The intervening cases fall into three groups with the cestuis being allocated three different sets of rights: (1) the right to fill vacancies among the trustees; (2) the right to elect trustees annually; (3) the right to elect trustees, to remove trustees

${ }_{16}$ Betts v. Hackathorn, 159 Ark. 621, 252 S. W. 602 (1929); Rhode Island Hospital Trust Co. v. Copeland, 39 R. I. 193, 9S Atl. 278 (1916); Mayo v. Moritz, 151 Mass. 481, 24 N. E. 1083 (1890). Though the liability of the cestuis to third persons was not involved in the following cases they are some authority for the point. Williams v. Milton, 215 IIass. 1, 102 N. E. 355 (1913) ; Bouchard v. First Pcople's Trust Co., 253 Mass. 351, 148 N. E. 895 (1925). Contra: Thompson v. Schmitt, 115 Tex. 58, 274 S. W. 554 (1925).

${ }_{47}$ Wells v. Mrackay Telegraph-Cable Co., 239 S. W. 1001 (Tex. 1022) is such a case. Liability was imposed. The holding is consistent with Thompson v. Schmitt, supia note 46. Technically there was an association since the cestuis not only adopted the declaration of trust at a mecting held for that purpose but thereby made provision for the other meetings. The entrepreneur test would probably impose liability since in addition to this association there were the profit, loss and ownership earmarlis in the cestuis. Cf. Magruder, The Position of Sharcholders in Business Trnets (1923) 23 CoL. L. Rev. 423, 428, 431; Rowley, The Influence of Control in the Determination of Partncrship Liability (1928) 26 IIICH. L. REv. 290, 296.

48 Morehead v. Greenville Exchange Nat. Banl, 243 S. W. 546 (Tex. 1922). 
and/or to alter and amend the trust indenture. The last is obviously sufficient for the purpose desired. It is even broader than . the control which the members of a joint stock company have, for by virtue of the right to amend the cestuis continually stand on the threshold of policy formulation. At any time they can not only oust the management but constitute themselves the "management. Such authority as there is imposes liability. ${ }^{40}$ Even the right to amend the articles might suffice. With that right the cestuis could strip the trustees of all control or regulate it as they wished. In fact they could no doubt become the policy formulators leaving the trustees as holders of naked legal title. That right would equip them with a capacity to distribute losses which would be at all times a potentiality if not an actuality. There is some authority that liability would be imposed."50 Cases where only the right to elect trustees and to remove them exists seem not to have been litigated. But if they arose it would seem apparent that, following this approach and observing the joint stock company analogy, liability would be imposed. The cestuis would then stand in a strategic position to formulate the policies desired through their subservient instrumentalities, the trustees. ${ }^{51}$ The first case is hardly doubtful. The type of control is very tenuous. The right may never be exerciseable since there may never be a vacancy. Not only is the right subject to

10 Frost v. Thompson, 219 Mass. 360, 106 N. E. 1009 (1914); Horgan v. Morgan, 233 Mass. 381, 124 N. E. 32 (1919). The position is taken in Magruder, op. cit. supra note 47 , at $434-435$, that the power to remove in these cases should not suffice as long as this right had not been exercised so as to interfere with and assume control of the business.

${ }^{60}$ Simson v. Klipstein, 262 Fed. 823 (D. N. J. 1920); McCarney v. Hollister Oil Co., 241 S. W. 689 (Tex. 1922). The Simson case is wenk since it involved not the question of the liability of the cestuis but the question of the necessity of joining the cestuis as parties plaintiff in an action against third persons for breach of contract. The sole question involved would seem to be, to whom did the promise run? That raises the question whether the name of the association, in which name the contract was signed, was the name of the trustees or the name of the cestuis. Obviously that has nothing to do with the question of vicarious liability. The McCarney case is weak because following Thompson v. Schmitt, supra note 46, liability would be imposed though no control was allocated to tho cestuis. The position is taken in Magruder, op. cit. supra note 46, at 437438 , that liability should not be imposed.

51 If the right to remove was unqualified this result would follow. If the right was qualified, it might not. Thus stockholders in corporations are sometimes denied the right by statute to remove directors without cause. If the declaration of trust or articles of association reserved to the cestuis only the right to remove trustees for cause, the case would seom to fall in the first of the three groups mentioned. "For cause" would not include a difference in judgment. It would include only breach of faith, etc. The trustees, as instrumentalities of the cestuis, would no longor appear subservient. 
this contingency but the right as, if and when exercised is of little potency in giving the cestuis the capacity desired. In the first place it does not assure election of all or a majority of the board. Secondly, once exercised no effective check is retained. The authority, though weak, is consistent with this view and indicates that no liability would follow:52 The second case is more troublesome. The right to elect all of the trustees annually is less tenuous than in the preceding case. The constitution not only of the majority but of the entire board can be regulated to a degree. And some check is reserved, for if the policies desired to be formulated are not, new representatives can be elected the ensuing year. The check is more tenuous than the right to remove; less tenuous than the right to fill vacancies. The projlem is again one of weighting this type of control. Does it give to the cestuis the capacity to keep an effective check on the fixing of prices and the determination of costs? It seems as if it does. If the selection were to be daily, the check would be tantamount to the right to remove. A weekly and possibly a monthly election would be the same. The interval for independent, unregulated discretion which a year provides is, to be sure, great. While the question is solely one of degree, the possibility of a failure to re-elect at the end of the year coupled with the fact that elected representatives are usually faithful to those who elect them and mindful of their wishes seems to give to the electors an effective check over policy formulation during the year. This control would probably suffice under the entrepreneur test to give the cestuis the control earmark and coupled with the other three and the element of association as evidenced by the provision for the annual meeting, make the cestuis liable. They not only look like enterprisers. They have the enterprisers' essential capacity. Liability should, therefore, be imposed under this test. Though the case is by no means beyond doubt, there is authority that the type of control is suf-

52 Smith v. Anderson, 15 Ch. D. 247 (1880). The case involved an action to have the property of an association distributed on the ground that the association was illegal by virtue of a statute providing that no "company, association, or partnership, consisting of more than twenty persons shall be formed ... for the purpose of carrying on any other business (than banking) that has for its object the acquisition of gain .... unless it is registered." It was held for the defendant. The court said, inter alia, at 280: "They (the cestuis) could not have been made liable on any contract made by the trustees." In Rand v. Miorse, 289 Fed. 389 (C. C. A. 8th, 1923), liability was imposed on the cestuis though the only type of control reserved by the cestuis was the right to elect the "successors" of the trustees. If the duration of the trustees' term of office was the life of the trust, the case is contrary to the position here taken. What the duration was is not revealed. The position is taken in Magruder, op. eit. supra note 47 , at 436 , that no liability should be imposed. 
ficient to entail liability. ${ }^{53}$ Of course, no such problem arises if the cestuis who are being sued are trustees. No matter how tenuous their control is as cestuis their control as trustees over policies would be present. Though the control as cestuis were absent, their control as trustees would be absolute. The fact that they might have one type of control as cestuis and another as trustees would make no difference in their capacity to distribute the losses in issue. The cases quite consistently impose liability in this case, in absence of a contract for limited liability..$^{54}$

The cases which are not in accord with this analysis and which cannot be aligned with the substantial majority of the cases are not necessarily wrong or unsound..$^{50}$ They would not fit into a logical system built around the rationale which has been presented. The opinions may be out of line with opinions in the partnership cases. But consistency is not the sole aim of law. The theory of liability which this essay advances does not embrace all stimuli that might induce courts to hold a group of individuals vicariously liable. It embraces only a few. There are others. The others cannot be fully understood unless the whole economic and social environment out of which the cases came are known. It may be that abuses were being committed under these new forms. It may be that they were merely susceptible of abuse. It is understandable if a court felt that limited liability should be attained only by the use of the devices specified by the legislature. ${ }^{56}$ On the other hand it is understandable if the legislature extends to cestuis who have full control limited liability. ${ }^{57}$ The test here advanced does not pretend to lay down a test that will lead to satisfactory

53 Rand v. Morse, supra note 52, is authority if the duration of the trustees' term of office was one year. It is not a holding on the precise point if the duration of the term was either the life of the trust or tho respective lives of the trustees. Even then, it is of some weight, for if liability were imposed in that case it surely would be in the case in question. But see Hamilton v. Young, 116 Kan. 128, 225 Pac. 1045 (1921); Homo Lumber Co. v. Hopkins, $107 \mathrm{Kan} .153,190$ Pac. 601 (1920). The formor case involved the liability of a trustee, not of the cestuis. The latter involved the question of the authority of the association to sell its stock in the state. The dicta are strong and unequivocal, however.

54 Neville v. Gifford, 242 Mass. 124, 136 N. T. 160 (1922); Howo v. Wichita State Bank \& Trust Co., 242 S. W. 1091 (Tex، 1922), aff'd, 115 Tex. 158, 274 S. W. 563 (1925), 278 S. W. 177 (1925).

t5 Thompson v. Schmitt, supra note 46; Wells v. Mackay TelegraphCable Co., supra note 47.

so Undue emphasis given to what the court has said rather than to what the court has done may lead to exaggerated notions of the import of tho decisions. For an example see Hildebrand, Massachusetts Trust-A Scqucl (1925) 4 TEX. L. REv. 57.

572 OKLA. Gen. LAws (1921) $\$ \$ 8465-8468$. The last section limits liability to third persons to the trust res. 
adjustments between conflicting economic and social forces in all cases. There may be stimuli which transcend all notions of risk distribution.

Furthermore this test gives no absolute weight to the various types of control. The type of control in question, though theoretically effective, may be actually ineffective for the purpose at hand. One variable causing such impotence might be absentee ownership. If that factor intruded, it might well be argued that the shareholders ceased to have the essential capacity of enterprisers, not only because they were in no position to supervise presently the formulators of policies, but also because they were in no strategic position to acquire such capacity in the future. One who of necessity votes by proxy, and does not have it in his power to make intelligent judgments in respect to the management, realistically does not have an effective check on policies to be formulated. Not only is his control tenuous. For all practical purposes it exists only when the essential nature or quality of his economic interest is to be changed. He has taken on the characteristics of the classical investor. He has lost the capacities of the classical entrepreneur. Such variable has not appeared in any of the cases of this type. If it did appear, clearly and unequivocally, the case might well go the other way on this rationale.

This analysis of the cases reveals remarkable uniformity in the holdings. It is not pretended that this rationale finds articulation in the opinions. It does however give to the control concepts, with which the opinions and literature abound and which have too often been assumed to have magical qualities, ${ }^{53}$ meaning and significance. Above all it attempts to furnish an economic and social basis for a rule of vicarious liability and to substitute for apologiae, at best inarticulate, an analysis that at least attempts to relate the legal problem to its economic and social environment. Such dynamic treatment does not conclude that the decisions are wrong. It merely puts them on a basis that makes possible a clearer articulation and a more careful analysis of the issues.

\footnotetext{
${ }^{58}$ Cf. Comment (1928) 37 Yaue I. J. 1103, 1120; Rowley, op. cit. supro note 47 .
} 